\title{
Key Factors in Reputation of Wines: Analysis of Wine-Production in Central Italy
}

\author{
Diotallevi F* and Marchini A \\ Department of Economics and Food Sciences, University of Perugia, Italy
}

Submission: September 06, 2017; Published: October 03, 2017

${ }^{*}$ Corresponding author: Diotallevi F, Department of Economics and Food Sciences, University of Perugia, Italy, Email: francesco.diotallevi@gmail.com

\begin{abstract}
Wine sector is just one of the most important drink sector in the modern market. In this global context, Europe and, in particular, Italy, play a critical role about demand and Supply. Traditional wine market is full, so it's necessary to find new lever to have consumers fidelity over time, first between all, the quality information. Wine is a product characterized by the existence of both significant differences in quality and asymmetric information between producers and consumers. In this context there is a natural incentive for wineries to market poor quality wines. However, evidence shows that wine markets are populated by high quality wines, as well as lower quality products. The present work aim to estimate, through a regression analysis, several variables extremely important to determine the quality wine reputation in Italian consumers. The aim of this article is to provide new evidence on the factors affecting wine prices on both methodological and factual grounds.The results have demonstrate the importance of some critics variable as wine characteristics and social-cultural aspects and, principally, the importance to take part on a DOC and DOCG. These results have a lot of important consequences in a strategic market chooses for companies.
\end{abstract}

\section{Introduction}

At the present, Wine is considered as a symbol of quality, as a smart lifestyle, as a modern approach to consumption, able to join the pleasure in assess taste and quality in foodstuffs (or in this case in drinks) with the emotions strictly related to the tradition and to the culture of a specific territory. In the wine-universe, as for many other food products, is becoming more and more important the synergism between the agricultural production and some new "output" of this system, like the rural landscape, the rediscovery of old traditions or the cultural identity in rural areas. Hence, it seems important to think a wine market that consider this strong interaction between different systems (touristic, environmental, socio-cultural and others) strictly related to the wine one, in order to transfer to the consumers the suitable reputation created by all these factors.

Different recent studies are focused on these aspects to define the dynamics of rural development and of the agro-food market [1]. In fact, the process of rural development can be considered as the search of a competitive advantage strictly related to specialities that a territory can produce. It is demonstrated that some kind of development, in rural areas, depend from the capacity to exploit the opportunity offered by macro dynamics. It happens for example when a traditional product uses a local and collective reputation to find a better position in the final market
When a local system establishes a personal PDO it uses an immaterial resource called collective reputation that seems to be important in the definition of the final notoriety of the product. A PDO can be considered as an institutional and juridical process to control and keep the collective reputation. The convenience consist into the possibility for producers to achieve some benefits (that come from collective reputation) in order to obtain a better income for all the geographical region Sisto et al.

This kind of resource can be considered collective and immaterial and it play an important role in local and rural dynamics of development, especially for what concern the particular specialities. In our case of study the collective reputation is propriety of the PDO, it is shared between the producers and, despite it is expensive to exclude other from the use, it can be restored in time Ostrom [2]. This mechanism it is theorized the reputation grows up, in the case of repeated purchasing, when the attributes that define the quality of a product are not detectable before the acquisition.

The single producer of a wine with a DOC or DOCG2 label can keep the benefits from a certain reputation, thanks to the past purchases of the consumer, even if the wine was produced by other firms of the same PDO. Hence, the reputation can be a dynamic signal of quality for the collective denomination of origin. 
Gergaud \& Livat [3], in a study about wine produced in Bordeaux areas, demonstrate that collective reputation can be considered as the simple addition of the "most famous" reputation among the producers of a PDO. It means that the better "member" of a PDO can drag the smaller producers that use the same collective reputation. According with the international literature, collective reputation can be considered as multivariable phenomena, coming from the interaction between complex dynamics defined through the management of some variables in space and in time.

The collective reputation is strictly related to the quality of the product and, in our case of study, most of its results depend from the intrinsic characteristic of the wine, defined in the PDO disciplinary. Analysing the wine market, we observed that some PDO are involved in phenomena of wave communication that are less related to the quality of wine, but that come from an aspect that we decided to define as notoriety.

In fact, notoriety is a very dynamic feature, involved in the bigger phenomena of collective reputation, but characterised by a higher variability in time and space and less influenced by the quality aspects of the products, but more influenced by some aspects coming from the socio-cultural contest of production. Thus, the aim of this study is to define which are the most important characteristics which influence the level of notoriety.

\section{Materials and Methods}

\section{Data set}

In order to obtain an empirical analysis we have created a database of some variables for each PDO that we assume relevant in the growing up of the notoriety. We have decided to divide this variables in three main groups:

Intrinsic features of wine: linked to organoleptic aspects, chemical standards and production technology explicitly imposed by the production disciplinary.

Socio-economical aspects: In the region of production: obtained principally from the census of population, industry and agriculture.

Aspects about notoriety: detected from an important wine guide that work at a national level.

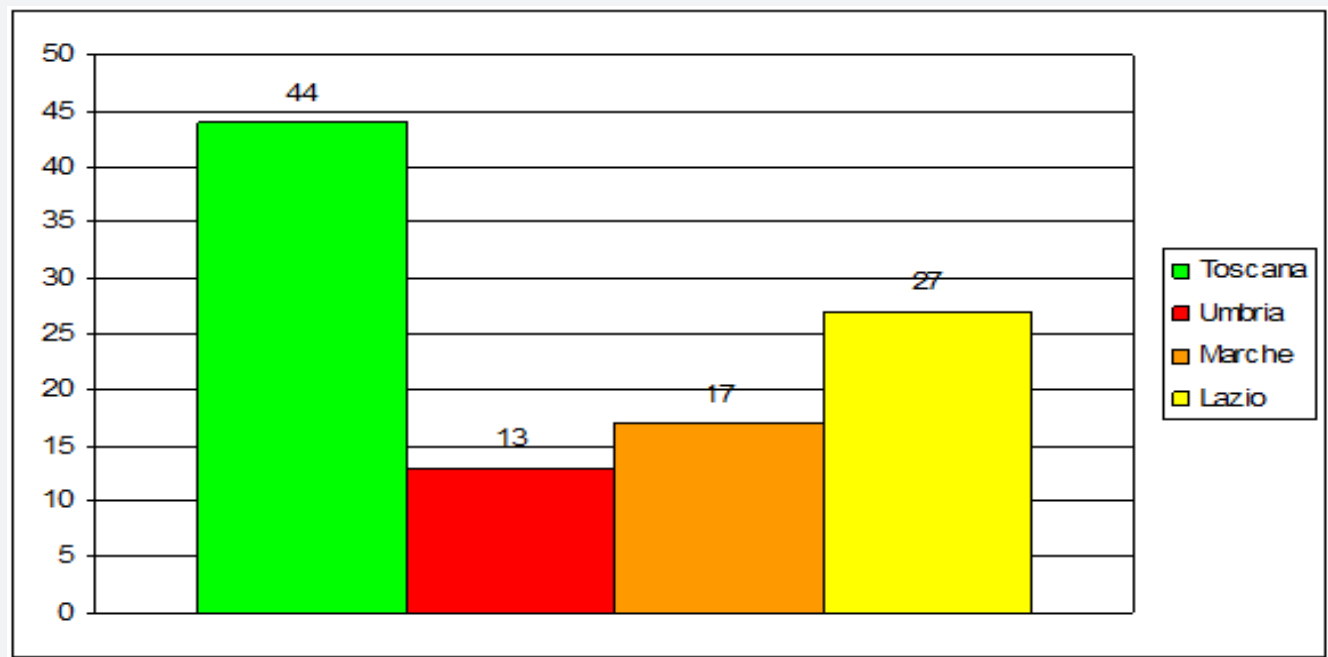

Figure 1: Total number of PDO in Central Italian Region. Data from: "wine denomination code" Caldano and Rossi 2008.

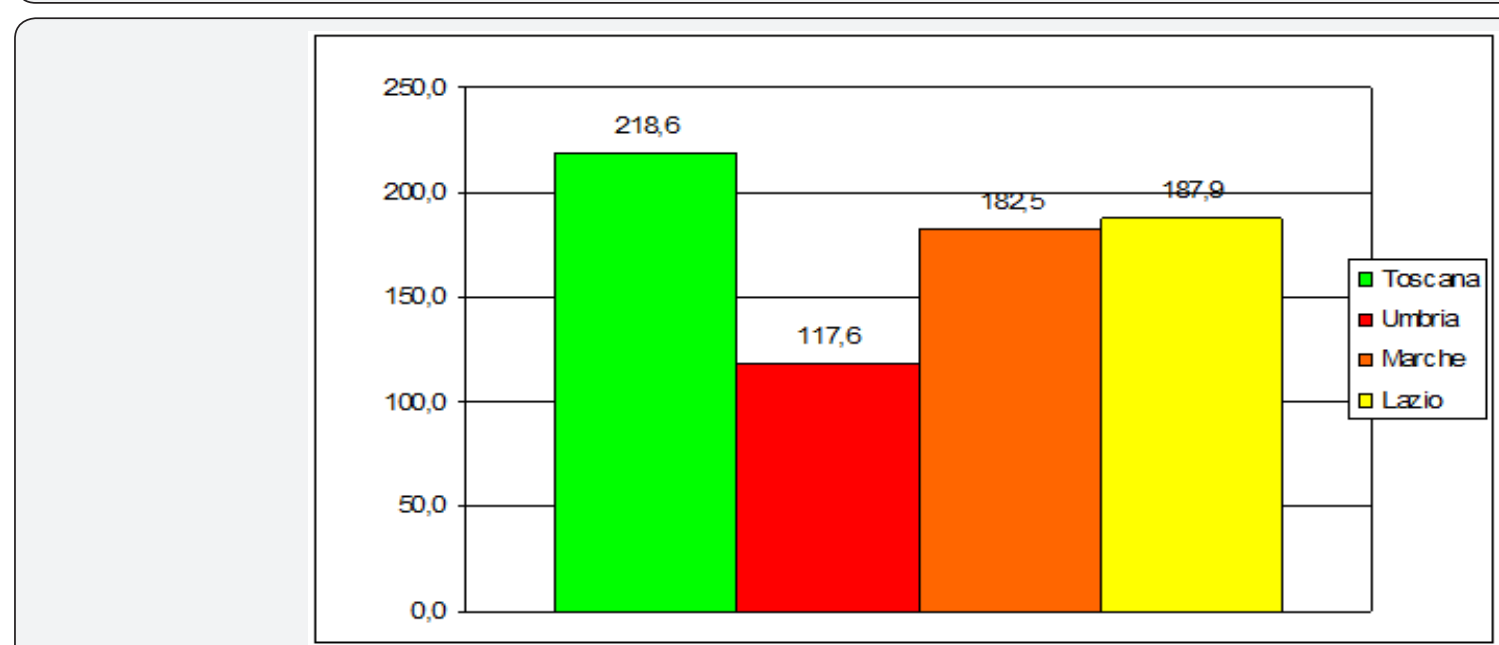

Figure 2: average number of producers for each PDO. Data from: "wine denomination code" Caldano and Rossi 2008. 
The intrinsic features of wines have been defined, according with Castriota \& Delmastro [4], analysing the national decrees rules of quality wines (i.e. DOCGs and DOC) published in the "wine denomination code" Caldano \& Rossi [5]. For each PDO the variables added to the database are:
a. The region.
b. If the PDO is a DOC or a DOCG.
c. The number of producers certified.
d. The age.

e. Minimum quality standards (MQS): like maximum yield of grape in wine, minimum alcohol content (\%), minimum acidity (grams per litre).

\section{f. Minimum time of aging (months).}

These characteristics can distinguish different wine belonging to the same PDO, but they must be achieved for what concerns the MCS. Still according with Castrioda \& Delmastro [4]. We have also decided to consider other variables (not compulsory for the producers but allowed by the national decrees), for example the presence of subclasses in a PDO, that can signify a higher level of quality. In Figures $1 \& 2$ there are some results about this data.

To describe the socio-economic contest of each PDOs area we considered the follow set of variables:
a. Population
b. Total surface of production
c. Number of bank office
d. Number of hotels
e. Number of Museums and archaeological area
f. Rate of urbanization
g. Employment rate in agriculture
h. Index of population dispersion
i. Feminine employment not in agriculture.

In order to define a level of notoriety for each PDO we have decided to use the guide "Duemilavini 2009" published by the Italian Association of Sommeliers", the advantages in using this guide is that it analyses the entire panorama of Italian wine products and the geography of production: describing territories, method of tasting, linking wines to the food production of each region and suggesting touristic proposals. It also introduces the single producers, including images about labels in order to help readers to remember each wine. Each wine receives a score that goes from 2 to 5 points. To collect this score in a single database, for every PDO we have built the following variables:

a. Ratio between producers awards and total number of producers ( $\mathrm{n}$ awards)

b. Average score obtained by each PDO.

\section{Statistical analysis}

We used a linear regression model to demonstrate the relations between the variables previously described. In a first approach, we have created some linear regression models using as dependent variable the number of awarded producers ( $\mathrm{n}$ awards); first results have demonstrated an important influence of these variable on the notoriety level. Deepening the analysis a specific need has arise: the necessity in using other dependent variables in order to divide the notion of notoriety from the usual determinants to catch some deeper relations, not yet analysed, that can introduce an innovative information in this type of studies. For this reason we used two different regression analysis considering as dependent variables the number of producers award (indicated by ' $\mathrm{N}^{\circ}$ awards') and an indicator of notorietygrowth (scores per year, indicated by 'glass-age'), less influenced by qualitative aspects. This last indicator has been chosen to understand if a higher score reached by a wine can influence the own level of notoriety and start or implement what we defined as wave communication.

\section{First model}

In the first analysis, we have assumed as dependent variable $\mathrm{N}^{\circ}$ award; the results of the regression have underlined significant independent variables belonging to both: wine characteristics and socio-cultural aspects:

a. Membership of DOCG: it requires higher standards, improving aspects of quality.

b. Number of bank office: it can express an economical liveliness of the area.

c. The presence of Subtitle "Classico" (indicated in output as "main"): it means that the wine is produced in a area belonging to the PDO since an old time, it gives to the product a added value.

d. The minimum alcohol content.

e. The maximum yield (winerate).

f. The presence of a sub-site of production.

g. The age.

h. The employment rate in agriculture.

i. The minimum time of aging (min.store).

j. The production of red wine.

The statistical results are resumed in Table 1-3.

\section{Second model}

The scope of the second model is to exclude the number of producers and the age of the PDOs. Castriota \& Delmastro [4] demonstrated that the number of producer cannot be linearly related to notoriety: in their study the relation between the two variables is proportional until the number of producers is low; while a higher growth of it implies a decrease of quality level 
and, consequently, of notoriety. Thus, it was essential to find a dependent variable less influenced from this aspect; for this reason we introduced the "number of score per year" (glass age), that express the growth rate of reached score in time. The score value is a dependent variable strictly related the wine quality, instead the variable used in the first method (number of awards producers), was most related directly to notoriety. Introducing this assumption it was possible to show that greater is the growth rate, greater will be the wave communication that a PDO can develop.

Table 1: Statistical results of the first model.

\begin{tabular}{|c|c|c|c|c|c|c|}
\hline & \multirow{2}{*}{ Model } & \multicolumn{2}{|c|}{ Non standardized Coefficients } & \multirow{2}{*}{$\begin{array}{c}\text { Standardized Coefficients } \\
\text { Beta }\end{array}$} & \multirow{2}{*}{$\mathbf{t}$} & \multirow{2}{*}{ Sig. } \\
\hline & & B & Standard error & & & \\
\hline \multirow[t]{2}{*}{1} & (Costant) & 4.632 & 1.278 & & 3.625 & 0.000 \\
\hline & docg & 22.55 & 3.814 & 0.517 & 5.912 & 0.000 \\
\hline \multirow[t]{3}{*}{2} & (Costant) & -6.526 & 3.442 & & -1.896 & 0.061 \\
\hline & docg & 20.099 & 3.682 & 0.460 & 5.459 & 0.000 \\
\hline & bank/1000 pop & 17.351 & 5.011 & 0.292 & 3.463 & 0.001 \\
\hline \multirow[t]{4}{*}{3} & (Costant) & -8.177 & 3.295 & & -2.481 & 0.015 \\
\hline & docg & 19.412 & 3.492 & 0.445 & 5.558 & 0.000 \\
\hline & bank/1000 pop & 18.524 & 4.758 & 0.312 & 3.893 & 0.000 \\
\hline & main & 15.604 & 4.521 & 0.272 & 3.451 & 0.001 \\
\hline \multirow[t]{5}{*}{4} & (Costant) & 32.162 & 9.17 & & -3.507 & 0.001 \\
\hline & docg & 16.899 & 3.491 & 0.387 & 4.84 & 0.000 \\
\hline & bank/1000 pop & 14.947 & 4.771 & 0.252 & 3.113 & 0.002 \\
\hline & main & 15.318 & 4.368 & 0.267 & 3.507 & 0.001 \\
\hline & min.alcool & 2.308 & 0.194 & 0.230 & 2.789 & 0.006 \\
\hline \multirow[t]{6}{*}{5} & (Costant) & -86.93 & 22.326 & & -3.894 & 0.000 \\
\hline & docg & 14.565 & 3.492 & 0.334 & 4.171 & 0.000 \\
\hline & bank/1000 pop & 14.87 & 4.621 & 0.250 & 3.218 & 0.002 \\
\hline & main & 16.366 & 4.247 & 0.284 & 3.846 & 0.000 \\
\hline & min.alcool & 4.032 & 1.029 & 0.402 & 3.92 & 0.000 \\
\hline & winerate & 0.518 & 0.194 & 0.256 & 2.674 & 0.009 \\
\hline \multirow[t]{7}{*}{6} & (Costant) & -82.146 & 22.007 & & 3.733 & 0.000 \\
\hline & docg & 15.204 & 3.438 & .348 & 4.423 & 0.000 \\
\hline & bank/1000 pop & 13.843 & 4.557 & .233 & 3.038 & 0.003 \\
\hline & main & 15.446 & 4.186 & .269 & 3.69 & 0.000 \\
\hline & min.alcool & 3.784 & 1.015 & .377 & 3.726 & 0.000 \\
\hline & winerate & 0.484 & 0.191 & .239 & 2.534 & 0.013 \\
\hline & sub.site & 5.404 & 2.505 & .158 & 2.157 & 0.034 \\
\hline \multirow[t]{8}{*}{7} & (Costant) & -88.455 & 21.666 & & -4.083 & 0.000 \\
\hline & docg & 15.582 & 3.362 & .357 & 4.635 & 0.000 \\
\hline & bank/1000 pop & 14.722 & 4.467 & 0.248 & 3.296 & 0.001 \\
\hline & main & 13.82 & 4.148 & 0.240 & 3.332 & 0.001 \\
\hline & min.alcool & 3.898 & 0.993 & 0.388 & 3.962 & 0.000 \\
\hline & winerate & 0.489 & 0.186 & 0.242 & 2.626 & 0.010 \\
\hline & sub.site & 6.04 & 2.462 & 0.177 & 2.453 & 0.016 \\
\hline & age & 0.183 & 0.079 & 0.168 & 2.322 & 0.023 \\
\hline \multirow[t]{5}{*}{8} & (Costant) & -88.937 & 20.957 & & -4.148 & 0.000 \\
\hline & docg & 15.863 & 3.252 & 0.363 & 4.878 & 0.000 \\
\hline & bank/1000 pop & 6.985 & 5.186 & 0.118 & 1.347 & 0.181 \\
\hline & main & 13.999 & 4.011 & 0.244 & 3.49 & 0.001 \\
\hline & min.alcool & 3.985 & 0.961 & 0.397 & 4.148 & 0.000 \\
\hline
\end{tabular}




\section{Agricultural Research \& Technology: Open Access Journal}

\begin{tabular}{|c|c|c|c|c|c|c|}
\hline & winerate & 0.459 & 0.181 & 0.227 & 2.543 & 0.013 \\
\hline & sub.site & 6.279 & 2.382 & 0.184 & 2.636 & 0.010 \\
\hline & age & 0.221 & 0.7 & 0.203 & 2.852 & 0.005 \\
\hline & agricul. Employ & 0.467 & 0.173 & 0.227 & 2.694 & 0.008 \\
\hline & \multirow{2}{*}{ Model } & \multicolumn{2}{|c|}{ Non Standardized Coefficients } & Standardized Coefficients & \multirow{2}{*}{$\mathbf{t}$} & \multirow{2}{*}{ Sig. } \\
\hline & & B & Standard Error & Beta & & \\
\hline \multirow[t]{10}{*}{9} & (Costant) & -87.897 & 20.575 & & -4.272 & 0.000 \\
\hline & docg & 17.512 & 3.288 & 0.401 & 5.327 & 0.000 \\
\hline & bank/1000 pop & 7.062 & 5.091 & 0.119 & 1.387 & 0.169 \\
\hline & main & 12.6 & 3.993 & 0.219 & 3.155 & 0.002 \\
\hline & min.alcool & 4.56 & 0.982 & 0.454 & 4.643 & 0.000 \\
\hline & winerate & 0.4 & 0.179 & 0.197 & 2.228 & 0.028 \\
\hline & sub.site & 6.527 & 2.341 & 0.191 & 2.788 & 0.006 \\
\hline & age & 0.214 & 0.076 & 0.197 & 2.811 & 0.006 \\
\hline & agricul. Employ & 0.474 & 0.17 & 0.230 & 2.783 & 0.007 \\
\hline & min.stor & -0.199 & 0.095 & -0.171 & -2.095 & 0.039 \\
\hline \multirow[t]{11}{*}{10} & (Costant) & -76.949 & 20.761 & & -3.706 & 0.000 \\
\hline & docg & 18.206 & 3.235 & 0.417 & 5.628 & 0.000 \\
\hline & bank/1000 pop & 6.87 & 4.986 & 116 & 1.387 & .172 \\
\hline & main & 13.499 & 3.932 & 0.235 & 3.433 & 0.001 \\
\hline & min.alcool & 4.357 & 0.966 & 0.434 & 5.51 & 0.000 \\
\hline & winerate & 0.218 & 0.194 & 0.108 & 1.124 & 0.264 \\
\hline & sub.site & 5.584 & 2.333 & 0.163 & 2.393 & 0.019 \\
\hline & age & 0.251 & 0.077 & 0.231 & 3.282 & 0.001 \\
\hline & agricul. Employ & 0.51 & 0.186 & 0.248 & 3.043 & 0.003 \\
\hline & min.stor & -0.261 & 0.097 & -0.225 & -2.684 & 0.009 \\
\hline & red & 5.003 & 2.304 & 0.173 & 2.185 & 0.032 \\
\hline
\end{tabular}

Table 2: Summary of the first model.

\begin{tabular}{|c|c|c|c|c|c|}
\hline Model & $\mathbf{R}$ & R-Squared & Corrected R-Squared & Standard Eximation Error & Durbin- Watson \\
\hline 1 & $0.517(\mathrm{a})$ & 0.267 & 0.259 & 1.191 .894 & 1.129 .022 \\
\hline 2 & $0.591(\mathrm{~b})$ & 0.349 & 0.335 & 1.069 .285 & 1.032 .704 \\
\hline 3 & $0.650(\mathrm{c})$ & 0.422 & 0.404 & 10.000167 & 980.875 \\
\hline 4 & $0.683(\mathrm{~d})$ & 0.467 & 0.444 & 958.040 & \\
\hline 5 & $0.711(\mathrm{e})$ & 0.505 & 0.478 & 926.365 & \\
\hline 6 & $0.728(\mathrm{f})$ & 0.529 & 0.498 & 909.223 & \\
\hline 8 & $0.746(\mathrm{~g})$ & 0.556 & 0.521 & & \\
\hline 9 & $0.768(\mathrm{~h})$ & 0.589 & 0.553 & 0.569 & \\
\hline 10 & $0.780(\mathrm{i})$ & 0.609 & 0.629 & 0.587 & \\
\hline
\end{tabular}

\footnotetext{
(a) Estimators: (Constant). docg
}

(b) Estimators: (Constant). docg. bank/1000 pop

(c) Estimators: (Constant). docg. bank/1000 pop. main

(d) Estimators: (Constant). docg. bank/1000 pop. main. min. alcool.

(e) Estimators: (Constant). docg. bank/1000 pop. main. min. alcool. winerate

(f) Estimators: (Constant). docg. bank/1000 pop. main. min. alcool. winerate. sub site.

(g) Estimators: (Constant). docg. bank/1000 pop. main. min. alcool. winerate. sub site. age

(h) Estimators: (Constant). docg. bank/1000 pop. main. min. alcool. winerate. sub site. age. agricult. employ 


\section{Agricultural Research \& Technology: Open Access Journal}

(i) Estimators: (Constant). docg. bank/1000 pop. main. min. alcool. winerate. sub site. age. agricult. Employ. min stor.

(j) Estimators: (Constant). docg. bank/1000 pop. main. min. alcool. winerate. sub site. age. agricult. Employ. min stor.. red

(k) Dependent variable: $n$.awards

Table 3: Residual statistic of the first model.

\begin{tabular}{|c|c|c|c|c|c|}
\hline & Minimum & Maximum & Average & Std. Deviation & N \\
\hline Attended value & -79.089 & 564.706 & 73.221 & 1.104 .335 & 99 \\
\hline Residual & -203.198 & 4.040 .545 & -0.10999 & 845.993 & 99 \\
\hline Std attended value & -1.372 & 4.488 & 0.014 & 1.005 & 99 \\
\hline Std residual & -2.282 & 4.538 & -0.012 & 0.950 & 99 \\
\hline
\end{tabular}

This time the results have demonstrated only five significant variables:

a. Membership of DOCG.

b. The employment rate in agriculture.

c. The number of agro-touristic firms. d. The presence of Subtitle "Classico" (indicated in output as "main").

e. The presence of Subtitle "Tardivo" (Old): it means a late harvest.

The statistical results are resumed in Table 4-6.

Table 4: Statistical results of the second model.

\begin{tabular}{|c|c|c|c|c|c|c|}
\hline \multirow{2}{*}{\multicolumn{2}{|c|}{ Model }} & \multicolumn{2}{|c|}{ Non Standardized Coefficients } & \multirow{2}{*}{$\begin{array}{c}\text { Standardized Coefficients } \\
\text { Beta }\end{array}$} & \multirow{2}{*}{ t } & \multirow{2}{*}{ Sig. } \\
\hline & & $P$ & & & & \\
\hline \multirow[t]{2}{*}{1} & (Costant) & 1.484 & 0.474 & & 3.133 & 0.002 \\
\hline & docg & 9.207 & 1.406 & 0.558 & 6.547 & 0.000 \\
\hline \multirow[t]{3}{*}{2} & (Costant) & .250 & 681 & & 0.368 & 0.714 \\
\hline & docg & 8.916 & 1.375 & 0.540 & 6.484 & 0.000 \\
\hline & agricul.employ & 0.160 & 0.065 & 0.205 & 2.465 & 0.016 \\
\hline \multirow[t]{4}{*}{3} & (Costant) & -0.277 & 0.696 & & -0.399 & 0.691 \\
\hline & docg & 8.256 & 1.365 & 0.500 & 6.050 & 0.000 \\
\hline & agricul.employ & 0.164 & 0.063 & 0.210 & 2.588 & 0.011 \\
\hline & Farm.house & 0.007 & 0.003 & 0.205 & 2.491 & 0.014 \\
\hline \multirow[t]{5}{*}{4} & (Costant) & -0.571 & 0.699 & & -0.817 & 0.416 \\
\hline & docg & 8.117 & 1.343 & 0.492 & 6.043 & 0.000 \\
\hline & agricul.employ & 0.175 & 0.062 & 0.224 & 2.799 & 0.006 \\
\hline & Farm.house & 0.007 & 0.003 & 0.206 & 2.542 & 0.013 \\
\hline & main & 3.563 & 1.734 & 0.164 & 2.055 & 0.043 \\
\hline \multirow[t]{6}{*}{5} & (Costant) & -0.570 & 0.688 & & -0.829 & 0.409 \\
\hline & docg & 7.781 & 1.333 & 0.471 & 5.836 & 0.000 \\
\hline & agricul.employ & 0.194 & 0.062 & 0.249 & 3.117 & 0.002 \\
\hline & Farm.House & 0.007 & 0.003 & 0.198 & 2.482 & 0.015 \\
\hline & main & 5.726 & 2.026 & 0.263 & 2.827 & 0.006 \\
\hline & old & -4.391 & 2.215 & -0.185 & -1.982 & 0.050 \\
\hline
\end{tabular}

Table 5: Summary of the second model.

\begin{tabular}{|c|c|c|c|c|c|}
\hline Model & R & R-Squared & Corrected R-Squared & Standard Eximation Error & Durbin- Watson \\
\hline 1 & $0.558(\mathrm{a})$ & 0.311 & 0.304 & 439.166 & \\
\hline 2 & $0.594(\mathrm{~b})$ & 0.353 & 0.339 & 427.884 & \\
\hline 3 & $0.627(\mathrm{c})$ & 0.393 & 0.374 & 416.503 & \\
\hline 4 & $0.648(\mathrm{~d})$ & 0.420 & 0.395 & 409.467 & 2.281 \\
\hline 5 & $0.666(\mathrm{e})$ & 0.444 & 0.413 & 403.098 & \\
\hline
\end{tabular}

(a) Estimators: (Constant). docg

(b) Estimators: (Constant). docg. agricul. employ 
(d) Estimators: (Constant). docg. agricul. Employ. Farm. House. main

(e) Estimators: (Constant). docg. agricul. Employ. Farm. House. main. old

(f) Dependent variable: glassage

Table 6: Residual statistic of the second model.

\begin{tabular}{|c|c|c|c|c|c|}
\hline & Minimum & Maximum & Average & Std. Deviation & N \\
\hline Attended value & -42.286 & 165.863 & 25.680 & 351.106 & 99 \\
\hline Residual & -866.913 & 2.515 .357 & -0.03214 & 391.726 & 99 \\
\hline Std attended value & -1.927 & 4.009 & 0.012 & 1.001 & 99 \\
\hline Std residual & -2.151 & 6.240 & -0.008 & 0.972 & 99 \\
\hline
\end{tabular}

This second analysis shows firstly how is significant, for the notoriety growing process of a PDO wine, to take part in a DOCG; hence it underlines the strong connection between quality and capacity in obtaining high score in the guide. In addition, the results underline the influence of the agricultural employment rate in the areas of production on the PDOs notoriety. It is well know that a strong and settled agriculture plays a key role in constructing the product image. Nowadays a strong agriculture is strictly bounded to the traditional rural contest, where the urbanization is marginal and the environment can preserve the original economic and agriculture vocation [5-11].

According with this scenario we can explain the influence of the agro-touristic firms on wine notoriety; this kind of multifunctional firms can be considered as promoter of the existing synergism between environment, local identity safeguard and agricultural production intensifying the connection among territories and final products [12-16].

That implies a positive influence on the collective image of the products, especially if we think at wine, involving in the contest tourism, local handicraft and territorial culture together with the environmental, historical and cultural heritage. Deepening the analysis of the results of the regression model the presence of subtitle "Classico"

For what concerns the presence of subtitle "Classico" for some PDOs in Central Italy, the results shows that it has a significant influence on notoriety construction. It is possible to contextualize this information if we consider the analysis contest; in Central Italy there are some PDO, as for example the Chianti one, in which the inclusion of mention "Classico" has helped in developing a better product statement with the same denomination, improving the quality perception of consumers. Hence, the variable that seems explain a different correlation with notoriety, are not the ones who describes the qualitative aspects, but are rather the ones involved in the linkage with territorial aspects [16-20].

\section{Conclusion}

The dynamics of world-wine market shows a deep crisis of consumption consequently to the economical and financial crisis. A Above all the medium-quality wines have suffered the main contraction; hence it seems necessary to define new strategy for their revival. The main aspect to consider is represented by the wine notoriety in markets in order to understand how notoriety is defined and how we can implement this process. In this work we analysed the construction process of collective reputation and the transfer of notoriety to a final product of a certain PDOs label. The first step was to define notoriety and collect data about some variables that we have defined as determinant in notoriety development. Than we use a statistical approach to study which variables influence more this process [1-27].

All the results obtained suggest useful ideas to use in political instruments for the regions analysed; the presence of an important number of high quality wines in guides demonstrates the need to operate in a context where the agricultural sector drives the entire welfare development. So, agriculture can be considered the main structure in socio-economical contest and the specific region analysed can became, in time and thanks to the introduction of coming policies, real wine-production district. Forcing this assumption, we can conclude asserting that firms can produce high quality wines, but to obtain an appropriate notoriety level they need to be strictly connected to territory trough the collective reputation of the PDOs, especially for what concerns the relevant variable out coming from the second model. We can demonstrate that the aspects involved in the process of notoriety growth, so strictly related to sociocultural development of the agricultural sector, are responsible of the wave communication that arise when there is a strictly connection between PDO wine and territory of production. The success, from a commercial point of view, consists in the fact that the consumer can find the emotion to know an entire coherent system around the single product.

\section{References}

1. Marchini A, Riganelli C, Diotallevi F, Paffarini C (2014) Factors of collective reputation of the Italian PDO wines: An analysis on central Italy. Wine Economics and Policy 3(2): 127-137.

2. Ostrom E (1996) Né mercato né stato nella gestione delle risorse collettive. La Questione Agraria 64: 7-39.

3. Gergaud O, Livat F, (2004) Team Versus Individual Reputation: a Model of Interaction and Some Empirical Evidence, Universitè de Reims Champagne-Ardenne Working Paper. 
4. Castriota S, Delmastro M (2009) The economics of collective reputation: minimum quality standards, vertical differentiation and optimal group size. American Association of Wine Economists, Working.

5. Caldano G, Rossi A (2008) Codice di denominazioni dei vini. Unione Italiana Vini (UIV).

6. Agrawal J, Kamamura WA (1999) Country of Origin: A competitive advantage? Internationl Journal of Research in Marketing, $n^{\circ} 16(1999)$ : 255-267.

7. Akerlof G (1970) The Market for Lemons: Quality Uncertainty and the Market Mechanism. The Quarterly Journal of Economics 84(3): 488500 .

8. Albisinni F (2008) La OCM vino: denominazioni di origine, etichettatura e tracciabilità del nuovo disegno disciplinare europeo.

9. Andersson F (2002) Pooling Reputations. International Journal of Industrial Organization 20: 715-730.

10. Belletti G (2001) Sviluppo Rurale: società, territorio, impresa.

11. Castriota S, Delmastro M (2008) Individual and collective reputation: lesson from the wine market. American Association of Wine Economists, AAWE, working Paper No 30.

12. Chiodo E (2006) Evoluzione dei mercati mondiali, riforma dell'Ocm Vino e competitività del settore vitivinicolo italiano.

13. Costanigro M, Cluskey MCJJ, Goemans C (2009) The economics of nested names: Name Specificity, Reputation and Price Premia. AAWE Working Paper No.49.

14. Faraoni M (2005) Notorietà di marca e vantaggio competitivo. VQ Mensile di Viticoltura ed Enologia, anno I - numero 2 - luglio/agosto 74-82.

15. Foxman ER, Berger PW, Cote JA (1992) Consumer brand confusion: a conceptual framework. In Psicology \& Marketing, 9 (2): 123-141.
16. Fleckinger P (2007) Collective reputation and market structure: Regulating the Quality vs. Quantity Trade-off. Discussion Paper, Ecole Polytechnique.

17. Green P, Christopher M (1976) Brand positioning. In European Marketing and Customers Syudies. Bradford.

18. Han CM, Terpstra V (1988) Country-of-origin effects for uninational and binational products. Journal of International Business Studies 19(2): 235-255.

19. Landon S, Smith C (1998) Quality Expectations, Reputation and Price. Southern Economic Journal 64(3): 628-647.

20. Maclnnis DJ, Shapiro S, Mani G (1999) Enhancing Brand Awareness Through Brand Symbols. Advances in Consumer Research 26: 601-608.

21. Pastore R (2002) Il marketing del vino e del territorio: istruzioni per l'uso. Angeli F (Ed.) 265-267.

22. Piccoli F (2007) Cresce nel mondo la cultura del vino. l'Informatore Agrario.

23. Russo A, Pantini D, Gordini P (2003) Wine marketing, il marketing del vino in Europa- consumi, canali, distributori e importatori. A cura di Nomisma, Agra. Ed. Hoepli 77: 93-102.

24. Scott SL, Johnson KF (2005) The Automatic Country-Of-Origin Effects On Brand Judgments. Journal of Advertising 34(1): 87-97.

25. Sudbodh B, Srinivas KR (1998) Symbolic and Functional positioning of brands. Journal of Customer marketing 15(1).

26. Tirole J (1996) A Theory of Collective Reputation (with Application to the Persistence of Corruption and to Firm Quality). Rewiev of Economics Studies 63(1):1-22.

27. Vescovi T, Gazzola P (2007)Immagine territoriale e identità globale. L'utilizzo del legame con il territorio nello sviluppo della marca. Micro \& Macro Marketing 3: 321-338.
This work is licensed under Creative Commons Attribution 4.0 License

DOI:10.19080/ARTOAJ.2017.11.555827
Your next submission with Juniper Publishers will reach you the below assets

- Quality Editorial service

- Swift Peer Review

- Reprints availability

- E-prints Service

- Manuscript Podcast for convenient understanding

- Global attainment for your research

- Manuscript accessibility in different formats

( Pdf, E-pub, Full Text, Audio)

- Unceasing customer service

Track the below URL for one-step submission https://juniperpublishers.com/online-submission.php 